\title{
Out of Sight, Out of Mind? The Impact of Natural Disasters on Pregnancy Outcomes
}

\author{
Emilia Simeonova
}

\author{
CESIFO WORKING PAPER No. 2814 \\ CATEGORY 10: ENERGY AND Climate ECONOMICS \\ OCTOBER 2009
}

Presented at CESifo Venice Summer Institute, July 2009
An electronic version of the paper may be downloaded
- from the SSRN website:
- from the RePEc website:
- from the CESifo website:
www.SSRN.com
www.RePEc.org
www.CESifo-group.org/wp




\title{
Out of Sight, Out of Mind? The Impact of Natural Disasters on Pregnancy Outcomes
}

\begin{abstract}
The impact of global climate change on health is not well understood. Besides the direct channel of increasing temperatures, there is a potentially more harmful one: through an increase in extreme weather incidents. We offer the first evidence on the effect of natural disasters on pregnancy outcomes. Elevated stress levels associated with extreme events increase the probability of a preterm birth. Preterm infants are more likely to be of low birth weight and are at increased risk of health problems later, implying even larger long run societal costs. Results confirm that exposure to extreme events increases the risk of preterm births.
\end{abstract}

JEL Code: I10, I12, Q54.

\author{
Emilia Simeonova \\ Tufts University \\ Economics Department \\ 8 Upper Campus Road \\ Braker Hall Room 110 \\ USA - Medford, MA 02155 \\ USA \\ Emilia.simeonova@tufts.edu
}

September $24^{\text {th }}, 2009$ 


\section{Introduction}

There is a growing economics literature on the effects of global warming on mortality (Deschenes and Moretti, 2007; Deschenes and Greenstone, 2007). These studies focus on the impact of increases in average temperatures or elevated temperature variability on concurrent mortality rates. However, global warming is also likely to influence the variability of weather, and the incidence of extreme weather events such as floods, landslides, severe storms and winter weather ${ }^{2}$. Besides the obvious direct effects through physical damage, these events may have more subtle, but equally important consequences for health.

This paper investigates the effects of exposure to extreme weather or weather-related events on pregnancy outcomes in the US between 1968 and 1988. Preterm births, defined as births before the $37^{\text {th }}$ week of gestation, are one of the major health problems in industrialized societies. They are the leading cause of infant mortality and are associated with substantial neurocognitive, pulmonary, and ophthalmologic problems later in life. Death rates among extremely pre-term infants (less than 31 weeks of gestation) are 170 times higher than among full term babies. Close to thirteen percent of all births in the US in 2006 were preterm. Moreover, care for premature babies is one of the most expensive items in medical care. A recent March of Dimes report estimates that the average cost of care for a premature baby is 49000 USD, as compared to 4551 USD for an uncomplicated full term birth infant. The costs of prematurity are almost five times higher than for any other complication of birth and delivery, resulting in at least 26.2 billion USD in societal costs each year (March of Dimes, 2008).

Previous research in medicine and sociology has shown that stress during pregnancy is associated with preterm births and inferior infant health outcomes (see e.g. Lauderdale, 2006; Dole et al, 2003; Collins et al, 2004). The obvious identification problem is one of omitted variable bias: mothers who report higher levels of stress may have other unobserved qualities which influence both stress levels and prematurity. Sudden events that exogenously increased the level of stress in mothers are rare. Exposure to natural disasters causes elevated levels of stress and anxiety in affected individuals (Shore et al (1986), Maida et al (1989)). Thus, it presents a "natural experiment” for the effects of increased maternal stress on pregnancy outcomes.

I find that exposure to extreme-weather related events in the 9 months before delivery increases the incidence of preterm births by 1.3 percent in the affected counties. The mean

\footnotetext{
2 The effect of global warming on hurricane formation and strength is not well understood.
} 
gestational age is close to half a week shorter, and the incidence of low birth weight increases. However, these results mask large differences in the effects of exposure at different times during the pregnancy. The timing of exposure matters - mothers affected in the second trimester of pregnancy suffer the largest negative impact on preterm deliveries. Similarly, gestational age and low birth weight are mostly affected by disasters happening in the second trimester of pregnancy. The duration of exposure, as well as the severity of the event also affect the chances of suboptimal pregnancy outcomes.

The rest of the paper is organized as follows. The next section summarizes the background and the previous literature on global warming, extreme weather events, and health. Section 3 describes the data and section 4 outlines the econometric strategy. The results of the empirical estimations are presented in Section 5. The last section concludes.

\section{Background and previous literature}

\subsection{Climate change and health}

There is little doubt that the global climate has changed in the last twenty years. In itself, a steady trend towards higher mean temperatures is likely to have significant health effects. A rarely examined but potentially more threatening channel through which climate change can affect welfare is through weather variability and the incidence of extreme weather and weather-induced events. Climate variability is expected to increase in a warmer world (McMichael et al, 2006).

Potentially, global climate change can affect interannual variability in the climate system, such as El Nino, which strongly influences disaster probabilities (van Aalst, 2006). Even though meteorological modeling and prediction of some types of extreme weather events, such as hurricanes and tornadoes, is highly inaccurate, statistics show that the number of people adversely affected by El Nino related events has increased greatly over the last three decades (Bouma et al, 1997). The 2003 heat wave in Europe, the recent inland floods in Great Britain, Central Europe, and the US, and the harsh hurricane seasons in the Atlantic have attracted considerable attention and even though it is not possible to accurately predict how often such events will occur in the future, it is worthwhile to estimate the damage incurred to date.

The most immediate consequences of climate change are the increased number of hot days and an intensification of the hydrological cycle, resulting in higher frequency of extreme rainfall 
events while at the same time there are more droughts. The Intergovernmental Panel on Climate Change (IPCC) also predicts increased tropical cyclone wind intensities and mean and peak precipitation intensities, as well as increased intensity of mid-latitude storms (IPCC2001a, table SPM-1). At least one climate model predicts that major cities in Europe and Northern America will be exposed to more frequent and more severe heat waves in the next century (Meehl and Tebaldi, 2004).

Humans may adapt to gradual climate change by purchasing goods which mitigate the health effects of weather changes. However, the occurrence of natural disasters is hard to predict in advance and stresses populations beyond the limits of adaptation. While some areas are more prone to suffer extreme weather events, e.g. their geographic location is in the frequent path of hurricanes, it is difficult to prepare for a disaster of an unknown magnitude which may strike at any time. Because disasters strike fast and their occurrence is unpredictable in most cases, they create plausibly exogenous variation in stress levels which may have damaging health consequences.

Besides the immediate and obvious harmful effects on infrastructure and the possibility of physical injuries which may result in the loss of life, weather-induced calamities have other "hidden" health consequences which may surface years after their incidence. Studies have shown increased levels of stress, anxiety, and depression among victims of natural disasters (Shore et al (1986), Maida et al (1989), Ollendick and Hoffmann (1982)). Krug et al (1999) report that in the four years after a disaster the incidence of suicides increases by 13.8 percent, by 31 percent in counties affected by hurricanes, and by 63 percent in the first year after earthquakes. Exposure to moderate-scale disasters with a small number of deaths and injuries has been linked to increased stress, especially for women. There is some evidence that a series of low-magnitude events such as tremors during an earthquake and higher resource loss result in higher levels of psychological distress (Freedy et al, 1994). Because extreme weather events and other natural disasters such as earthquakes and avalanches happen suddenly and cause high levels of stress, they create plausibly exogenous variation in the anxiety levels of the affected populations.

\subsection{Stress and pregnancy outcomes}

The exact biological mechanism which links increased levels of maternal stress and prematurity is not precisely known. The medical and epidemiological literature suggest that the increased production of neuropeptide coricotropin-releasing hormone (CRH) during periods of 
anxiety plays a role in initiating labor. Women with elevated blood levels of CRH in the second trimester or early third trimester are at a higher risk of preterm deliveries (Hobel et al. 1999; Holzman et al. 2001; McLean et al. 1999; Wadhwa et al. 1998). Maternal stress measured at different gestational ages has been found to correlate significantly with CRH measured at the same time, and including levels of $\mathrm{CRH}$ as controls has been found to mediate the relationship between maternal stress and preterm delivery (Mancuso, 2004).

There has been a steady trend in the incidence of preterm births in the US since the 1990s. The percentage of infants delivered at less than 37 completed weeks of gestation has climbed 20 percent since 1990. Most of this rise is attributable to the increases in late preterm births (34-36 weeks), which is up 25 percent since 1990. The singleton preterm rate also increased in 2006, to 11.1 percent. This rate has climbed 14 percent since 1990. About 25 per cent of all pre-term births nowadays in the US are medically induced to prevent future complications for the mother or the child. The proportion of induced births was much lower in the 60s and 70s. Pre-term births are hard to predict and have been linked to maternal smoking, infection, and stretching of the uterus. Lower socio-economic status, pregnancy too early or too late in the mother's reproductive period, and race are also significant predictors of prematurity. In 2006 11.7\% of white mothers delivered prematurely, compared to 18.5 percent of African Americans.

Studies that use exogenous variations in stress levels to estimate the effect of stress on prematurity are rare. Lauderdale (2006) demonstrates that Arabic women in California in the wake of 9/11 were more likely to have preterm and low birth weight babies than Arabic women in the same period the year before. She attributes the increase in poor pregnancy outcomes to increased stress due to perceived ethnic discrimination against distinctly Arabic populations in the months after 9/11. Camacho (2007) uses the explosion of land mines in Colombia to test the effects of increased exposure to terrorist attacks on pregnancy outcomes. She finds that increased incidence of land mine explosions during pregnancy is a significant predictor of low birth weight infants and preterm deliveries. The effects are especially pronounced if stress happens in the first and last trimesters.

It is not well established whether maternal anxiety is particularly harmful at some periods during pregnancy. We know little about the connection between stress generated by external stressors such as unfavorable weather conditions and preterm deliveries. Does the number of distinct events matter? Are short and sudden extreme weather episodes such as a tornado more 
damaging that long and (more likely) anticipated ones (such as a flood)? Does the extent of damage and loss of life matter? Are the effects of natural disasters mediated by socio-economic status?

There is a growing economics literature on the effects of climate on mortality. Deschenes and Moretti (2007) examine the impact of extremely hot and cold days on contemporaneous and overall mortality. While heat waves mostly affect the infirm and can be seen as "harvesting" of later deaths earlier, extreme cold days are associated with an increase of almost 700 deaths per day. But the economics literature offers little evidence on the effect of adverse weather conditions during pregnancy on pregnancy outcomes such as prematurity. One strand of research has concentrated on shocks to maternal health while the baby is in utero on the child's outcomes later in life (Almond, 2006, Almond et al, 2009, Almond and Mozumdar, 2007). However, these studies do not examine the immediate effects of adverse conditions during pregnancy, which manifest in short-term outcomes such as pre-term deliveries. Moreover, psychological distress arising from increased anxiety does not necessarily manifest in insults to physical health such as a decrease in the mother's immune defense.

The closest study to this one in design is by Glynn et al (2001) who examine the effects of a strong earthquake on stress and prematurity in pregnant women in California. They find that exposure to stress in early gestational ages increases the reported levels of stress and decreases gestational age at delivery. The study is important because it traces both increases in stress levels and preterm delivery, contributing more direct evidence on the relationship between the two. However, their sample size is small (281 women) and representative only of one county in California.

\section{Data sources and summary statistics}

The infant health data were drawn from the national vital statistics, which cover the period 1968-1988. The period is restricted until 1988 because the National Center for Health Statistics stopped reporting the county of residence for the mothers after 1988. The Vital Statistics data are collected from birth certificates by the states on all births which took place on the state's territory in each year. The data contain a great deal of detail about the birth and the conditions of the newborn. The estimated gestation and the birth weight of the infant have been collected since the first issue of 
the statistics in 1968. The county and state of residence of the mother are also included. To maintain anonymity, exact dates of birth are not released. However, the month of birth is recorded.

The Vital Statistics data contain two geographic identifiers - the county of birth and the county of residence for the mother. There are two reasons why the latter is a better geographic unit of analysis. First, dislocation due to extreme weather is not uncommon. Second, since the emphasis is on the effects of events which happened during the pregnancy, it is important what happened in the mother's county of residence, not in the county where the birth took place. A potential problem is that mothers who were dislocated due to a natural disaster may report their present county of residence rather than the location where they resided at the time of the adverse event. However, this is more likely to happen if the mothers permanently relocate, and the decision to completely abandon one's permanent residential location is not immediate. Moreover, studies show that most the residents who are forced to leave their houses move internally within the same county or state. For example, internal migration after hurricane Andrew (1990) was mostly within the same county (76\%), the neighboring county (9\%) or elsewhere in Florida (9.2\%). The majority of moves were short lived $-67 \%$ of those who moved returned to their residences within 12 weeks. Yet a nontrivial 8.2\% took more than a year to come back (Smith and McCarty, 1996). In the wake of hurricane Katrina, with the exception of New Orleans county, between 80 and 90 per cent of dislocated residents moved elsewhere within the same county (US Census Bureau, 2006).

Table 1 reports summary statistics for the infant health data. Twenty percent of expectant mothers were affected by a natural disaster for each of the 9 months before delivery. In total, 70\% of mothers in the period 1968-1988 were exposed to an extreme weather event during the 9 months before delivery. There are very small differences in demographic characteristics and outcomes among mothers affected by any disaster and those who were not. The prevalence of older (over 35 years of age) mothers similar in the two groups while minority mothers form a higher proportion in counties affected by any disaster.

One way to measure the extent of the disaster's impact is by the number of fatalities. The second part of Table 1 shows comparisons in means between mothers affected by an extreme event which resulted in at least one fatality and the rest. Only one sixth of mothers were exposed to disasters which resulted in fatalities. The differences are stronger between those affected by a fatal disaster and those who were not. Mothers residing in counties which were affected by a fatal 
disaster during the 9 months before the month of birth are more likely to have delivered prematurely, to have low birth weight babies and to be African American.

Table 1: Means of key variables in the vital statistics data

\begin{tabular}{l|l|l}
\hline \multicolumn{2}{c}{ All registered disasters } \\
\hline N mothers & Adverse event during pregnancy & $\begin{array}{l}\text { No adverse event during } \\
\text { pregnancy }\end{array}$ \\
\hline Mean prematurity & 36591951 & 9276024 \\
\hline Mean gestational age (weeks) & .09 & .09 \\
\hline Mean lbw & 39.4 & 39.4 \\
\hline Teen mother & & \\
\hline Mother over 35 & .067 & .0649 \\
\hline Black race & .14 & .14 \\
\hline
\end{tabular}

\begin{tabular}{l|l|l}
\hline \multicolumn{2}{c}{ Disasters with 1+ fatalities } \\
\hline N mothers & 8953867 & 36914108 \\
\hline Mean prematurity & .10 & .09 \\
\hline Mean gestational age (weeks) & 39.3 & 39.4 \\
& & \\
\hline Mean lbw & .071 & .065 \\
\hline Teen mother & .14 & .14 \\
\hline Mother over 35 & .044 & .04 \\
\hline Black race & .20 & .14 \\
\hline
\end{tabular}

The infant health data were collapsed on the month-year-county of residence cell and merged with the natural disasters data. Disasters occurring in the county of residence of the mother in the month of birth and the nine months before the delivery were linked to the birth. So for example, a birth in May 1968 was linked to all natural disasters occurring in the county of residence of the mother between August 1967 and May 1968. This is necessary because several different measures of exposure to extreme events were constructed. First, an indicator variable equal to one if there were any extreme events in the county of residence of the mother in the nth month before delivery $(0<=n<=9)$. Second, a count variable for the total number of disasters in the county/month cell. Several different events may strike the same county during a month. For example, a tornado and several severe storms in one month are not very unusual in Midwestern states in spring/summer. Third, the average duration of disasters on the in the county/month cell was calculated using data on individual disasters. Fourth, only disasters resulting in one of more fatalities were considered. 
Finally, the total amount of property damage, injuries and fatalities were aggregated on the county/month cell.

The natural disasters data contain information on the incidence and duration of a calamity. They were obtained from the Spatial Hazard Events and Losses Database for the United States (SHELDUS) version 6.2. SHELDUS is a county-level hazard data set for the U.S. for 18 different natural hazard events types such thunderstorms, hurricanes, floods, wildfires, and tornados. For each event the database includes the beginning date, location (county and state), property losses, crop losses, injuries, and fatalities that affected the county. Table 2 reports the types and counts of different disasters included in the database over the period 1968-1988.

The definition of a natural disaster in this paper follows the definition of the National Climatic Data Center, which provided most of the data in the SHELDUS database. The data contained in SHELDUS were derived from several existing national data sources such as National Climatic Data Center's monthly Storm Data publications and NCDC's Tsunami Event Database. For the period between 1960 and 1995 only those events that generated more than \$50,000 1960 USD in damages or at least one death were included in SHELDUS. This means that as time progresses, relatively smaller disasters are included in the dataset. At the same time, the average number of people killed in a disaster decreases over time as infrastructure and disaster warning technologies improve. Figure 1 shows the number of counties affected by natural calamities between 1967 and 1986. There does not appear to be a clear indication of increased reporting over time such as an upward trend in the number of affected counties. I present a number of different approaches to control for these changes in disaster reporting in the empirical models.

Over the period 1968-1986 the largest number of calamities in a county-year happened in counties in Kansas and Mississippi in 1971 and in Kansas in 1972. Eleven different events classifiable as natural disasters hit those counties. The state which suffered the worst in human lives lost in a single year was Kentucky, which lost over 290 lives to adverse weather events in 1971. 
Table 2: Descriptive statistics of the SHELDUS natural disasters data for the period 1968-1988

\begin{tabular}{lll}
\hline Type of disaster & $\mathrm{N}$ fatal disaster incidents & $\begin{array}{l}\text { Number of unique disaster } \\
\text { incidents }\end{array}$ \\
\hline Avalanche & 3 & 8 \\
\hline Coastal weather & 12 & 32 \\
\hline Heat waves & 33 & 78 \\
\hline Tornados & 63 & 599 \\
\hline Floods & 233 & 1068 \\
\hline Fog & 11 & 18 \\
\hline Winter weather & 375 & 1115 \\
\hline Severe Storms & 240 & 1612 \\
\hline Hurricanes & 20 & 72 \\
\hline Earthquakes & 5 & 15 \\
\hline Landslides & 2 & 15 \\
\hline Hail & 48 & 1151 \\
\hline Wild fires & 7 & 14 \\
\hline Strong winds & 152 & 991 \\
\hline Other disasters & 496 & 1788 \\
\hline & & \\
\hline Average property damage & 203000 USD & \\
\hline Mean N fatalities & 0.25 & \\
\hline Mean duration & 1.2 days & \\
\hline
\end{tabular}

A natural disaster can affect more than one county and make several landfalls over time. For example, hurricane Katrina first crossed over Florida as a category 1 hurricane, and only 5 days later made its famous landfall in New Orleans as a category 3 hurricane. To account for the different ways of reporting disasters I present two types of disaster statistics. The number of unique disasters are counted as the number of unique events which affected a county in the continental US. Different incidents involving the same disaster were counted separately if they took place over different time periods. Under this methodology, Katrina’s landfall in Louisiana will be counted as one disaster, and Katrina's landfall over Florida as another. The second method is to count the total number of affected counties by any given disaster, where each county is counted separately. This is equivalent to defining a disaster on the county level, where a flood affecting two neighboring counties will be considered two separate disasters.

A large number of natural disasters strike the US every year and they affect a large proportion of the population. Figure 1 A presents the disasters data in two formats: the total unique disasters which 
happened in a calendar year and the number of counties affected by those disasters. The dotted lines in both plots show the same trends but restricted to fatal disasters only. There is a discernible upward trend in the number of extreme events between 1968 and 1988 and the fluctuations associates with El Nino are clearly visible. Despite the increase in disaster count, the number of affected counties appears to have declined, suggesting a more short-lived and geographically contained impact.

Figure 1 A: Number of affected counties by natural disasters and unique counts of disasters, 19681986
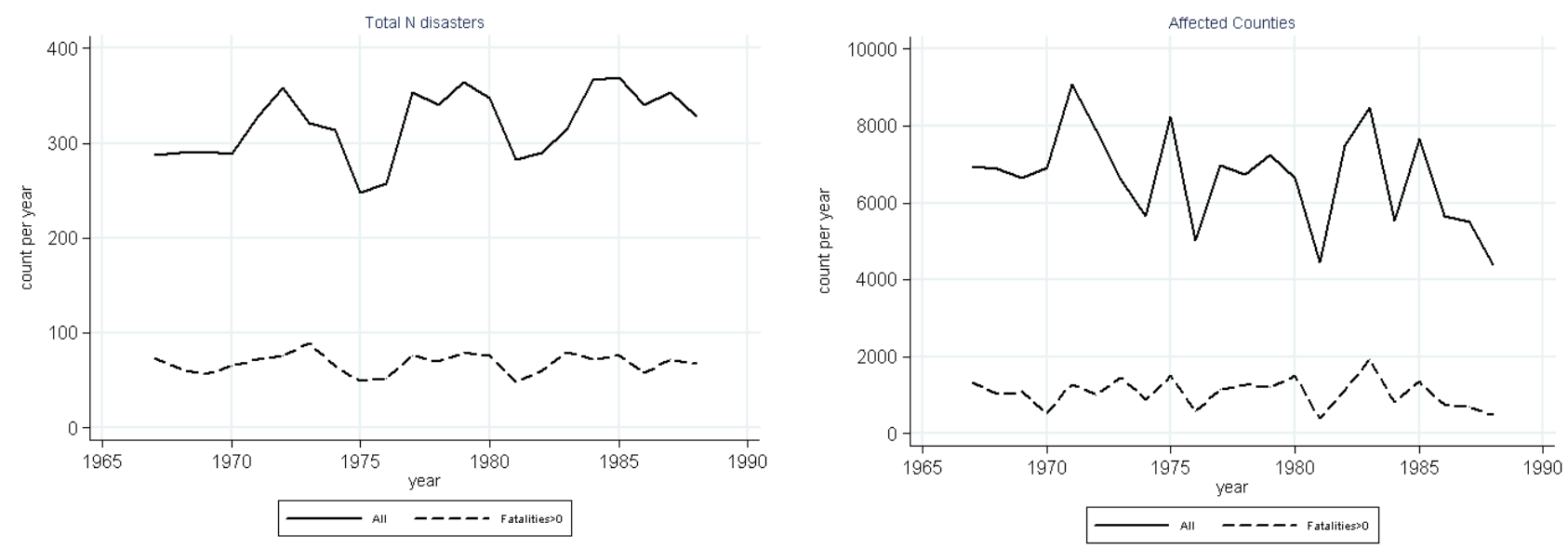

Figure 1B : Incidence of disasters by disaster type
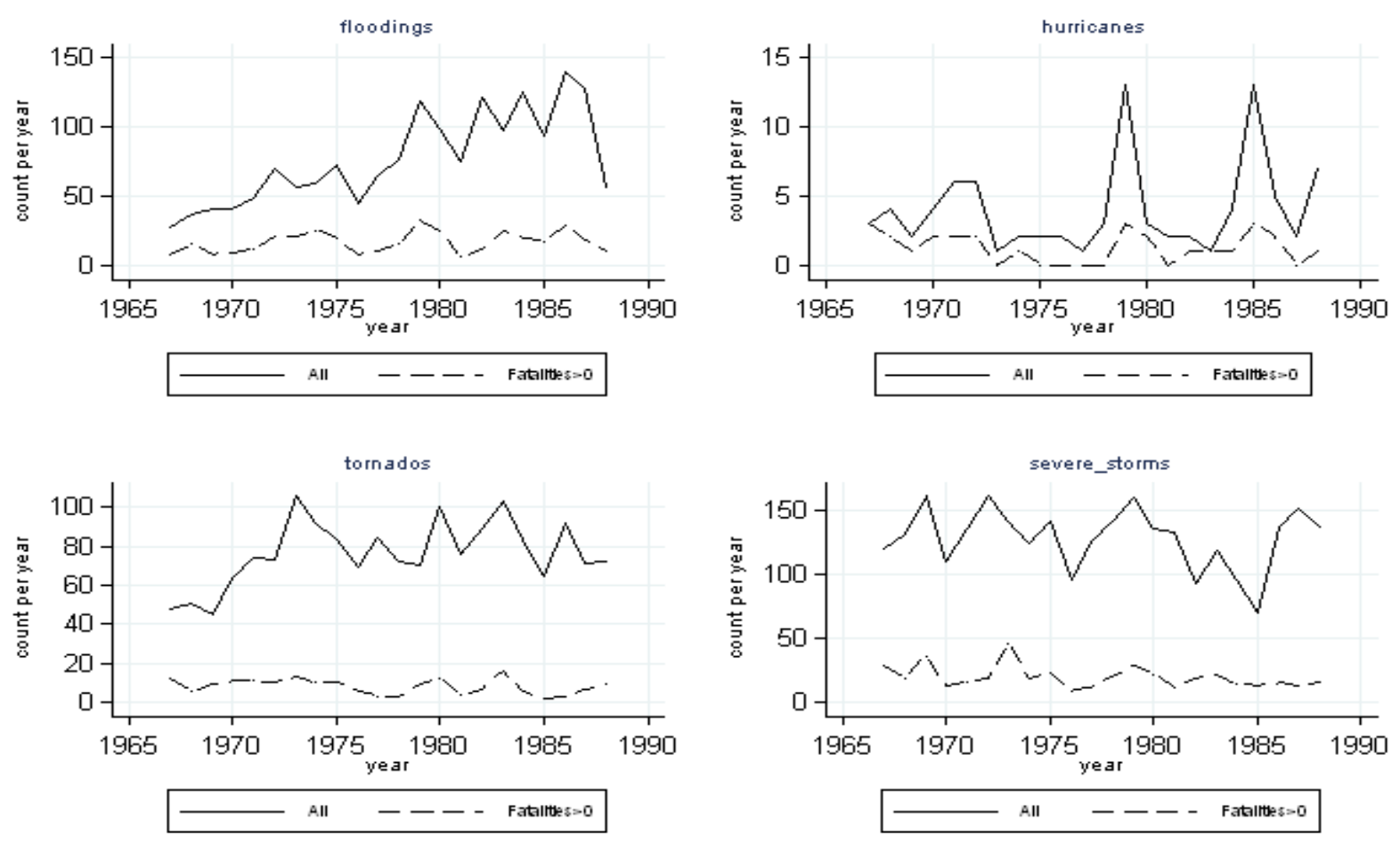

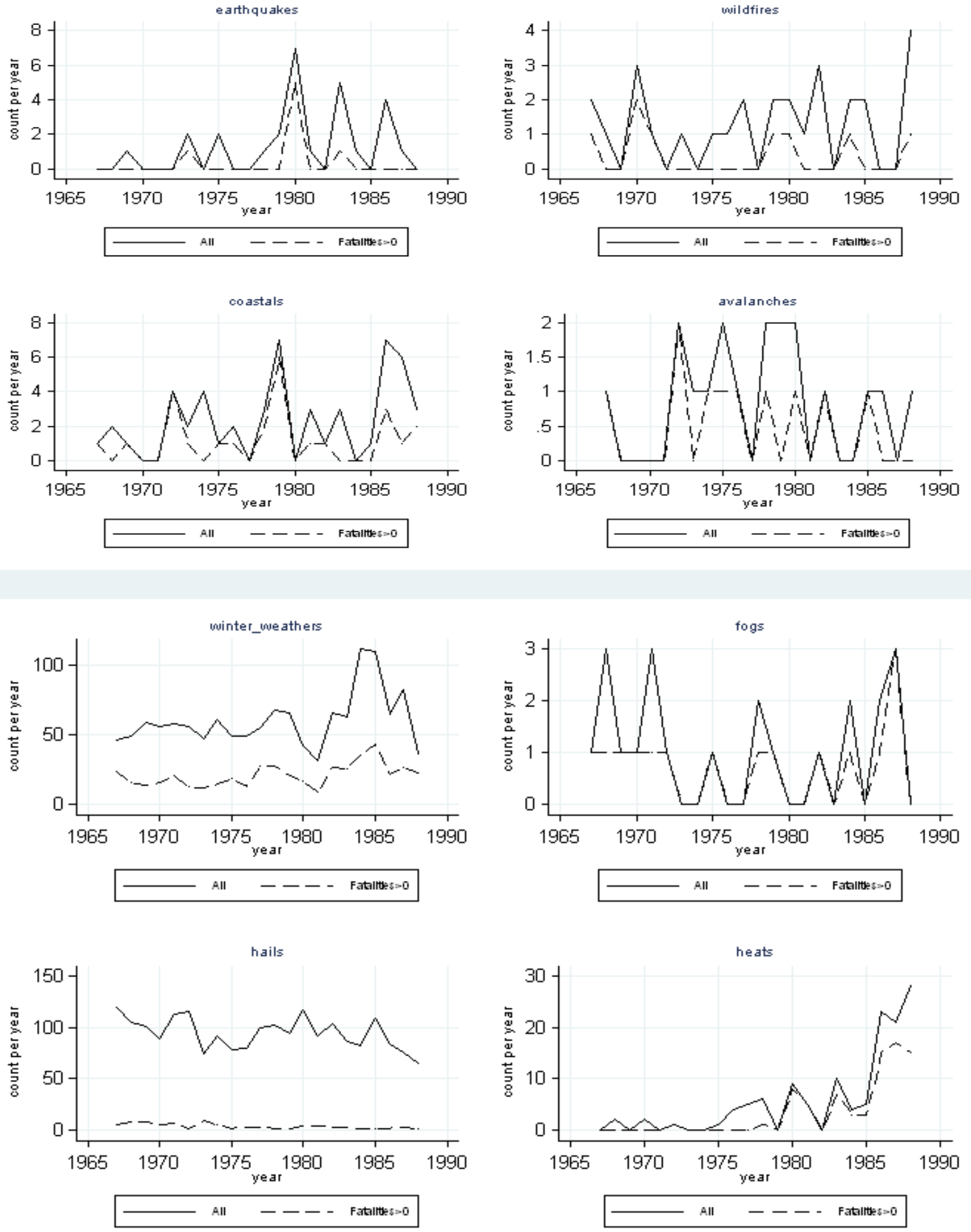
Figure 1B shows the incidence of disasters by disaster types. There are clear upward trends in the incidence of floodings, tornados, heat waves, and extreme winter weather episodes. The incidence of wild fires and hurricanes also seems to have become more common. The number of fatalities associated with heat waves and winter weather also show a steady increase through the 80s, perhaps giving an early warning of what came later in the 90s and 2000s. These figures are based on basic means and show a clear trend which suggests changes in the incidence and severity of extreme weather events in starting in the 1980s.

Figure 2 shows the average number of injuries and the number of fatalities resulting from natural disasters in the period 1968-1988. After a spike in the early 1970s, there is little variation in the number of injuries per year. The number of fatalities also stays almost constant from year to year.

Figure 2: Average number of injuries per county due to natural disasters 1968-1988

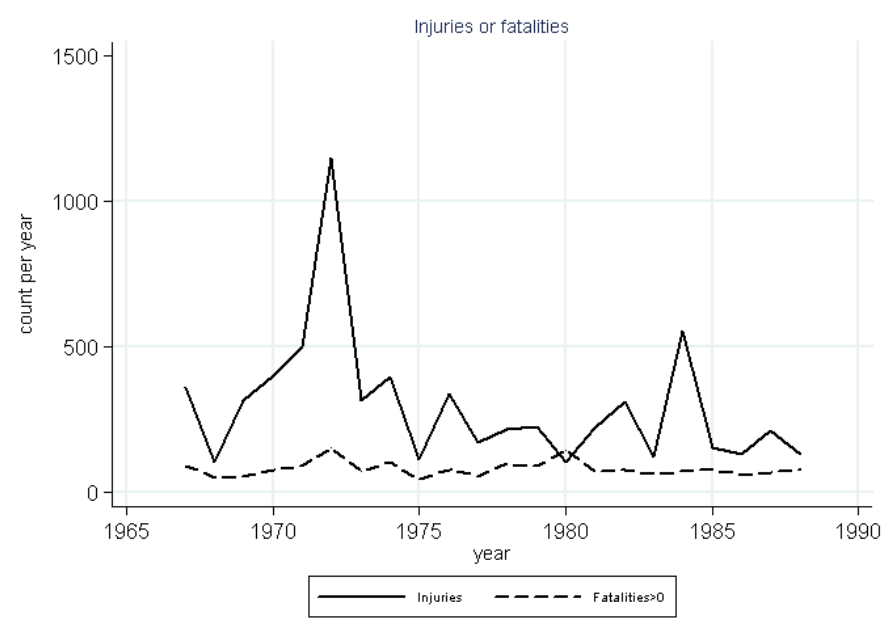

\section{Econometric Strategy}

The identification strategy relies on the unpredictability of the timing of extreme weather events. While some locations are more prone to disasters, the exact time when the adverse event happens is not known in advance. To control for increased exposure to extreme events due to geography, I include county fixed effects in the baseline specification. Yearly variations in weather are taken out by year fixed effects. Some moths are more prone to disastrous weather. For example, hurricane season covers the period September - November. Month dummies and month*year dummies are included in the empirical estimation. 
Several outcomes are particularly interesting. First, disasters increase stress levels and stress in pregnant women has been linked to premature deliveries. The first set of outcomes is based on the average incidence of prematurity for mothers exposed to weather-related and other calamities during the nine months before delivery compared to those who were not.

The empirical model is:

Outcome $_{\text {imt }}=\beta^{*}$ Disaster $_{i}+C+M+T+\varepsilon_{\text {imt }}$

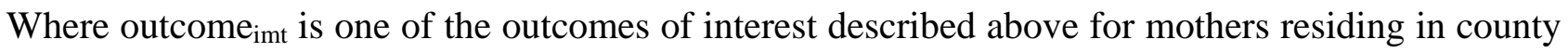
$\mathrm{i}$ in month $\mathrm{m}$ of year $\mathrm{t}$, Disaster ${ }_{\mathrm{imt}}$ is a dummy variable taking the value 1 if there was a natural disaster in the county during the nine months before the birth, $\mathrm{C}$ is a county-level fixed effect, $\mathrm{M}$ is a month of delivery dummy and $\mathrm{T}$ is a year of delivery fixed effect. The preferred specification across all models includes month*year and county*year fixed effects.

Next, I examine whether there are "key periods" during the pregnancy when exposure to an extreme weather event is more likely to result in prematurity. The model becomes:

Outcome $_{\text {imt }}=\sum_{j==9}^{0} \beta_{j} *$ Disaster $_{i j}+C+M+T+\varepsilon_{i m t}$

Where $\beta_{j}$ are coefficients for months 0 to -9 before delivery, and disaster ${ }_{\mathrm{ij}}$ is an indicator an extreme weather event in the $\mathrm{j}$ month before delivery. I also include specifications which control for the number of disasters, to capture the effect of repeated exposure to stress within the jth month of pregnancy.

More sever natural disasters may cause larger increases in prematurity. To test this hypothesis I use two of the measures of severity available in the SHELDUS database - the number of fatalities and the amount of property damage.

Outcome $_{\mathrm{imt}}=\sum_{j==9}^{0} \gamma_{j} *$ Severity $_{i j}+C+M+T+\varepsilon_{i m t}$

Where Severity $\mathrm{ij}_{\mathrm{ij}}$ is the number of fatalities due to an extreme weather event in the jth month before delivery or the sum of property damage in the county due to a disaster inflicted in the jth month before delivery.

The duration of the extreme event may also be important. However, it is not clear what is the mechanism. A flash flood may last a day but cause extreme stress, while a heat wave may last a 
week but with proper warning may not be as disruptive. To investigate how the duration of the extreme conditions affects the probability of premature births, I formulate the following models:

Outcome $_{\mathrm{imt}}=\sum_{j==9}^{0} \beta_{j} *$ Disaster_duration $_{i j}+C+M+T+\varepsilon_{i m t}$

and

Outcome $_{\mathrm{imt}}=\sum_{j==9}^{0} \beta_{j} *$ severity $_{i j}+C+M+T+\varepsilon_{i m t}$

\section{Results}

\subsection{Basic estimation}

Table 3 reports the results from estimations of the average effect of exposure to a natural disaster during pregnancy on prematurity, gestational age and the incidence of low birth weight. The model in column 1 controls for month and year of birth fixed effects, as well as county fixed effects. In the second column I add year-month fixed effects, which control for all common unobserved factors which could influence mothers who gave birth in each month of each year in the US. The final column adds county-year fixed effects, controlling for all common factors affecting all mothers in the same county-year cell.

Mothers who were exposed to an extreme weather event had a 0.1 percentage points higher chance of a preterm delivery than those who were not. This corresponds to a 1.3 percent increase with a mean prematurity rate of $7.6 \%$. The difference in gestational age is -0.01 , or a decrease of 2.8 days. There are no discernible effects on LBW.

Table 3: Impact of extreme weather events on prematurity, gestational age and LBW A: Prematurity

\begin{tabular}{l|lll}
\hline & $(1)$ & $(2)$ & $(3)$ \\
\hline & & & \\
Affected during & -0.000 & -0.000 & $0.001^{* *}$ \\
pregnancy & & & \\
& $(0.000)$ & $(0.000)$ & $(0.000)$ \\
Month of birth FE & YES & NO & YES \\
Year FE & YES & NO & NO \\
Year-month FE & NO & YES & NO \\
County FE & YES & YES & YES \\
County*year FE & NO & NO & YES \\
Constant & $0.085^{* * *}$ & $0.078^{* * *}$ & $0.076^{* * *}$ \\
& $(0.001)$ & $(0.002)$ & $(0.001)$ \\
\hline
\end{tabular}




\begin{tabular}{l|lll}
\hline Observations & 695019 & 695019 & 695019 \\
R-squared & 0.056 & 0.056 & 0.193 \\
Robust standard errors in parentheses & &
\end{tabular}

* significant at $10 \%$; ** significant at $5 \%$; *** significant at $1 \%$

B: Gestational age

\begin{tabular}{l|lll}
\hline & $(1)$ & $(2)$ & $(3)$ \\
\hline & & & \\
Affected during & $-0.008^{* *}$ & $-0.008^{* *}$ & $-0.010^{*}$ \\
pregnancy & & & \\
& $(0.003)$ & $(0.003)$ & $(0.005)$ \\
Month of birth FE & YES & NO & NO \\
Year FE & YES & NO & NO \\
Year-month FE & NO & YES & YES \\
County FE & YES & YES & YES \\
County*year FE & NO & NO & YES \\
Constant & $39.596^{* * *}$ & $39.511^{* * *}$ & $39.553^{* * *}$ \\
& $(0.011)$ & $(0.022)$ & $(0.006)$ \\
Observations & 695019 & 695019 & 695019 \\
R-squared & 0.067 & 0.068 & 0.190 \\
Robust standard errors in parentheses & & \\
\hline \multirow{2}{*}{ significant at $10 \% ; * *$ significant at $5 \% ; * * *$ significant at $1 \%$} & \\
\hline
\end{tabular}

C: Low Birth Weight

\begin{tabular}{l|lll}
\hline & $(1)$ & $(2)$ & $(3)$ \\
\hline & & & \\
$\begin{array}{l}\text { Affected during } \\
\text { pregnancy }\end{array}$ & 0.000 & 0.000 & 0.000 \\
& $(0.000)$ & $(0.000)$ & $(0.000)$ \\
Month of birth FE & YES & NO & NO \\
Year FE & YES & NO & NO \\
Year-month FE & NO & YES & YES \\
County FE & YES & YES & YES \\
County*year FE & NO & NO & YES \\
Constant & $0.058 * * *$ & $0.072 * * *$ & $0.065^{* * *}$ \\
& $(0.001)$ & $(0.002)$ & $(0.000)$ \\
Observations & 695019 & 695019 & 695019 \\
R-squared & 0.045 & 0.045 & 0.131 \\
Robust standard errors in parentheses & & \\
\hline * significant at $10 \% ; * *$ significant at $5 \% ; * * *$ significant at $1 \%$ & \\
\hline
\end{tabular}

A natural extension is to consider the effect of exposure during different months in the pregnancy. Tables 4 A, B and C report these estimates. To save space, only months with coefficients different from zero are reported. The first three columns consider the effect of a continuous measure of 
disaster exposure (the count of natural disasters striking the county of residence in the given pregnancy month). Columns 4-6 report the effect from a binary exposure variable. The comparison group in both models are mothers who were not exposed to a natural disaster during the month, but may have been exposed to an extreme event in a different gestational period. A more restrictive definition of a natural disaster is used in the model in columns 7-9, namely a disaster which resulted in one of more fatalities. The comparison here is between mothers who experienced such a disaster in the month and all other mothers, including those who lived through a less severe calamity.

In the preferred and most restrictive model including county-year and month of the year fixed effects, exposure to an extreme event in the $3^{\text {rd }}$ or $4^{\text {th }}$ month before delivery significantly increases the chance of a premature birth. Premature births happen after less than 37 weeks of gestation, implying that exposure in or around the second trimester has the most detrimental consequences. Exposure in 2 consecutive months would result in a 0.2 percentage points increase in the probability of a premature delivery, or over 2 percent increase over the mean prematurity rate. Calamities involving fatalities appear particularly harmful if they happen two months before birth. These effects also imply increased vulnerability in the second or early third trimester of pregnancy.

Curiously, exposure in very early gestational periods or before conception appears to have the opposite effects. The coefficient on the $6^{\text {th }}$ month before delivery is unanimously negative and significant throughout specifications. Moreover, exposure to a severe disaster with fatalities before conception appears to decrease the prematurity rate significantly. There are two possible explanations for these phenomena. First, selective mobility where mothers who are a priori more likely to have an early delivery permanently re-locate after a natural disaster in their county could be driving the results. This is particularly relevant in the case of fatal disasters, where exposure in the month before estimated conception for full-term babies has a negative effect on the prematurity rate. Second, if stress in early pregnancy is particularly harmful, then the most vulnerable fetuses could have been aborted resulting in a positive selection among the cohort. These hypotheses are explored in a later section. 
Table 4A: The effect on prematurity by month of exposure

\begin{tabular}{|c|c|c|c|c|c|c|c|c|c|}
\hline \multicolumn{10}{|c|}{ Prematurity } \\
\hline \multicolumn{2}{|l|}{$\begin{array}{l}\text { Exposure } \\
\text { period }\end{array}$} & \multicolumn{2}{|l|}{$\mathrm{N}$ disasters } & \multicolumn{3}{|c|}{ Binary Disaster } & \multicolumn{3}{|c|}{ With fatalities } \\
\hline \multirow{2}{*}{$\begin{array}{l}\text { M before } \\
\text { birth }\end{array}$} & 0.000 & 0.000 & 0.000 & 0.000 & 0.000 & 0.001 & $0.003^{*}$ & $0.002 *$ & 0.002 \\
\hline & $(0.000)$ & $(0.000)$ & $(0.000)$ & $(0.000)$ & $(0.000)$ & $(0.000)$ & $(0.001)$ & $(0.001)$ & $(0.001)$ \\
\hline \multirow{2}{*}{$\begin{array}{l}3 \mathrm{~m} \text { to } \\
\text { birth }\end{array}$} & 0.000 & $0.000 *$ & $0.001 * *$ & 0.000 & 0.000 & $0.001 * *$ & 0.002 & 0.002 & 0.002 \\
\hline & $(0.000)$ & $(0.000)$ & $(0.000)$ & $(0.000)$ & $(0.000)$ & $(0.000)$ & $(0.001)$ & $(0.001)$ & $(0.001)$ \\
\hline \multirow{2}{*}{$\begin{array}{l}4 \mathrm{~m} \text { to } \\
\text { birth }\end{array}$} & 0.000 & 0.000 & $0.000 *$ & 0.001 & 0.001 & $0.001 * *$ & -0.000 & -0.000 & -0.000 \\
\hline & $(0.000)$ & $(0.000)$ & $(0.000)$ & $(0.000)$ & $(0.000)$ & $(0.000)$ & $(0.001)$ & $(0.001)$ & $(0.001)$ \\
\hline \multirow{2}{*}{$\begin{array}{l}6 \mathrm{~m} \text { to } \\
\text { birth }\end{array}$} & - & - & $-0.000 *$ & - & - & $-0.001 * *$ & 0.000 & 0.000 & -0.000 \\
\hline & $\begin{array}{l}0.001 * * * \\
(0.000)\end{array}$ & $\begin{array}{l}0.001 * * * \\
(0.000)\end{array}$ & $(0.000)$ & $\begin{array}{l}0.001 * * * \\
(0.000)\end{array}$ & $\begin{array}{l}0.001 * * * \\
(0.000)\end{array}$ & $(0,000)$ & $(0.001)$ & $(0.001)$ & (0 001) \\
\hline \multirow{2}{*}{$\begin{array}{l}7 \mathrm{~m} \text { to } \\
\text { birth }\end{array}$} & 0.000 & 0.000 & 0.000 & 0.000 & 0.000 & 0.000 & 0.002 & 0.002 & 0.002 \\
\hline & $(0.000)$ & $(0.000)$ & $(0.000)$ & $(0.000)$ & $(0.000)$ & $(0.000)$ & $(0.001)$ & $(0.001)$ & (0.002) \\
\hline \multirow{2}{*}{$\begin{array}{l}8 \mathrm{~m} \text { to } \\
\text { birth }\end{array}$} & -0.000 & -0.000 & -0.000 & -0.000 & -0.001 & -0.000 & -0.001 & -0.001 & -0.001 \\
\hline & $(0.000)$ & $(0.000)$ & $(0.000)$ & $(0.000)$ & $(0.000)$ & $(0.000)$ & $(0.001)$ & $(0.001)$ & $(0.001)$ \\
\hline \multirow{2}{*}{$\begin{array}{l}9 \mathrm{~m} \text { to } \\
\text { birth }\end{array}$} & -0.000 & -0.000 & -0.000 & 0.000 & -0.000 & 0.000 & $-0.003^{* *}$ & $-0.003^{* *}$ & $-0.003^{*}$ \\
\hline & $(0.000)$ & $(0.000)$ & $(0.000)$ & $(0.000)$ & $(0.000)$ & $(0.000)$ & (0.001) & $(0.001)$ & (0.001) \\
\hline Year FE & YES & NO & NO & Yes & NO & NO & Yes & No & NO \\
\hline $\begin{array}{l}\text { M of } \\
\text { birth FE }\end{array}$ & Yes & NO & NO & Yes & NO & NO & Yes & NO & NO \\
\hline $\begin{array}{l}\text { County } \\
\text { FE }\end{array}$ & Yes & Yes & $\mathrm{NO}$ & Yes & Yes & NO & Yes & Yes & NO \\
\hline $\begin{array}{l}\text { Month- } \\
\text { year FE }\end{array}$ & NO & YES & NO & NO & YES & NO & NO & YES & NO \\
\hline $\begin{array}{l}\text { County- } \\
\text { year FE }\end{array}$ & NO & NO & YES & NO & $\mathrm{NO}$ & YES & NO & $\mathrm{NO}$ & YES \\
\hline Constant & $\begin{array}{l}0.099 * * * \\
(0.001)\end{array}$ & $\begin{array}{l}0.102 * * * \\
(0.003)\end{array}$ & $\begin{array}{l}0.091 * * * \\
(0.001)\end{array}$ & $\begin{array}{l}0.099 * * * \\
(0.001)\end{array}$ & $\begin{array}{l}0.102 * * * \\
(0.003)\end{array}$ & $\begin{array}{l}0.090 * * * \\
(0.001)\end{array}$ & $\begin{array}{l}0.099 * * * \\
(0.001)\end{array}$ & $\begin{array}{l}0.101^{* * *} \\
(0.003)\end{array}$ & $\begin{array}{l}0.091^{* * *} \\
(0.000)\end{array}$ \\
\hline Obs & 695019 & 695019 & 695019 & 695019 & 695019 & 695019 & 695019 & 695019 & 695019 \\
\hline R-sq & 0.052 & 0.053 & 0.179 & 0.052 & 0.053 & 0.179 & 0.052 & 0.053 & 0.179 \\
\hline \multicolumn{10}{|c|}{ Robust standard errors in parentheses } \\
\hline \multicolumn{10}{|c|}{$*$ significant at $10 \%$; ** significant at $5 \%$; *** significant at $1 \%$} \\
\hline \multicolumn{10}{|c|}{$\begin{array}{l}\text { The effects on gestational age follow closely the results for prematurity. Exposure in the last five } \\
\text { months before delivery causes an increase in the rate of prematurity. Extreme events in two } \\
\text { consecutive months during the second trimester would result in a } 5.1 \text { per cent decrease in } \\
\text { gestational age. Again, exposure during very early gestation or before conception has the opposite } \\
\text { effect on gestational age. }\end{array}$} \\
\hline
\end{tabular}


Table 4B: The effects on gestational age by month of exposure

\section{Gestational age}

\begin{tabular}{|c|c|c|c|c|c|c|c|c|c|}
\hline $\begin{array}{l}\text { Exposure } \\
\text { period }\end{array}$ & \multicolumn{3}{|c|}{$\mathrm{N}$ disasters } & \multicolumn{3}{|c|}{ Binary Disaster } & \multicolumn{3}{|c|}{ With fatalities } \\
\hline $\begin{array}{l}\text { M of } \\
\text { birth }\end{array}$ & 0.001 & 0.001 & -0.002 & 0.000 & -0.000 & -0.003 & -0.002 & -0.001 & 0.003 \\
\hline & $(0.002)$ & $(0.002)$ & $(0.002)$ & $(0.003)$ & $(0.003)$ & (0.004) & $(0.013)$ & (0.014) & $(0.014)$ \\
\hline M before & -0.001 & -0.000 & -0.004 & -0.002 & -0.001 & -0.004 & - & $-0.024 *$ & -0.015 \\
\hline & $(0.002)$ & $(0.002)$ & $(0.003)$ & (0.003) & (0.004) & (0.004) & $\begin{array}{l}0.026^{* *} \\
(0.012)\end{array}$ & $(0.012)$ & $(0.013)$ \\
\hline $2 \mathrm{~m}$ to & 0.000 & -0.001 & $-0.004^{*}$ & 0.001 & -0.000 & -0.005 & 0.007 & 0.008 & 0.012 \\
\hline & $(0.002)$ & $(0.002)$ & (0.003) & $(0.003)$ & $(0.003)$ & (0.004) & $(0.011)$ & (0.011) & $(0.013)$ \\
\hline $\begin{array}{l}3 \mathrm{~m} \text { to } \\
\text { birth }\end{array}$ & $0.005 * *$ & $0.006 * *$ & $\begin{array}{l}- \\
0.008 * * \\
*\end{array}$ & $0.008 * *$ & $0.008 * *$ & $\begin{array}{l}- \\
0.012 * *\end{array}$ & -0.010 & -0.008 & -0.006 \\
\hline & $(0.002)$ & $(0.002)$ & $(0.002)$ & $(0.003)$ & $(0.003)$ & $(0.004)$ & $(0.012)$ & $(0.012)$ & $(0.014)$ \\
\hline $\begin{array}{l}4 \mathrm{~m} \text { to } \\
\text { birth }\end{array}$ & -0.004 & $-0.004^{*}$ & $0.007 * *$ & $-0.006^{*}$ & $0.007 * *$ & $0.010 * *$ & -0.008 & -0.010 & -0.005 \\
\hline & $(0.002)$ & $(0.002)$ & $(0.003)$ & $(0.003)$ & (0.003) & (0.004) & $(0.013)$ & (0.013) & $(0.014)$ \\
\hline $5 \mathrm{~m}$ to & 0.001 & 0.001 & -0.002 & 0.000 & 0.001 & -0.001 & 0.009 & 0.009 & 0.014 \\
\hline & $(0.002)$ & $(0.002)$ & $(0.002)$ & $(0.003)$ & $(0.003)$ & (0.004) & $(0.012)$ & $(0.012)$ & $(0.014)$ \\
\hline $\begin{array}{l}6 \mathrm{~m} \text { to } \\
\text { birth }\end{array}$ & $\begin{array}{l}0.006^{* *} \\
*\end{array}$ & $\begin{array}{l}0.007^{* *} \\
*\end{array}$ & 0.004 & $0.008^{* *}$ & $\begin{array}{l}0.009 * * \\
*\end{array}$ & $0.007^{*}$ & 0.000 & 0.001 & -0.003 \\
\hline & $(0.002)$ & $(0.002)$ & (0.003) & (0.003) & $(0.004)$ & $(0.004)$ & $(0.012)$ & $(0.012)$ & $(0.013)$ \\
\hline $7 \mathrm{~m}$ to & -0.000 & -0.001 & -0.003 & -0.002 & -0.003 & -0.004 & 0.004 & 0.002 & 0.001 \\
\hline & $(0.002)$ & $(0.002)$ & (0.003) & (0.003) & (0.003) & (0.004) & $(0.014)$ & (0.014) & $(0.015)$ \\
\hline $8 \mathrm{~m}$ to & -0.001 & -0.000 & -0.002 & -0.001 & 0.001 & -0.000 & 0.011 & 0.008 & 0.010 \\
\hline & $(0.002)$ & $(0.002)$ & $(0.002)$ & (0.003) & $(0.003)$ & (0.004) & $(0.012)$ & $(0.012)$ & $(0.013)$ \\
\hline $9 \mathrm{~m}$ to & -0.001 & -0.001 & -0.003 & -0.003 & -0.002 & -0.004 & $0.027^{*}$ & $0.026^{*}$ & 0.017 \\
\hline & $(0.002)$ & $(0.002)$ & (0.003) & $(0.003)$ & (0.004) & (0.004) & $(0.014)$ & (0.014) & $(0.014)$ \\
\hline Year FE & YES & NO & NO & Yes & NO & NO & Yes & No & NO \\
\hline $\begin{array}{l}\text { M of birth } \\
\text { FE }\end{array}$ & Yes & NO & NO & Yes & NO & NO & Yes & NO & NO \\
\hline $\begin{array}{l}\text { County } \\
\text { FE }\end{array}$ & Yes & Yes & NO & Yes & Yes & NO & Yes & Yes & NO \\
\hline $\begin{array}{l}\text { Mon/year } \\
\text { FE }\end{array}$ & NO & YES & NO & NO & YES & NO & NO & YES & NO \\
\hline $\begin{array}{l}\text { County/ye } \\
\text { ar FE }\end{array}$ & NO & NO & YES & NO & NO & YES & NO & NO & YES \\
\hline Const & $\begin{array}{l}39.497 * \\
* *\end{array}$ & $\begin{array}{l}39.496 * \\
* *\end{array}$ & $\begin{array}{l}39.544 * \\
* *\end{array}$ & $\begin{array}{l}39.498 * \\
* *\end{array}$ & $\begin{array}{l}39.497 * \\
* *\end{array}$ & $\begin{array}{l}39.543 * \\
* *\end{array}$ & $\begin{array}{l}39.496 * \\
* *\end{array}$ & $\begin{array}{l}39.496 * \\
* *\end{array}$ & $\begin{array}{l}39.527 * \\
* *\end{array}$ \\
\hline
\end{tabular}




\begin{tabular}{llllllllll}
\hline & $(0.009)$ & $(0.030)$ & $(0.005)$ & $(0.009)$ & $(0.030)$ & $(0.005)$ & $(0.009)$ & $(0.030)$ & $(0.004)$ \\
Obs & 695019 & 695019 & 695019 & 695019 & 695019 & 695019 & 695019 & 695019 & 695019 \\
R-sq & 0.069 & 0.070 & 0.191 & 0.069 & 0.070 & 0.191 & 0.069 & 0.070 & 0.191 \\
\multicolumn{1}{l}{ Robust standard errors in parentheses } \\
* significant at 10\%; ** significant at 5\%; *** significant at 1\% \\
\hline
\end{tabular}

The effects on low birth weight are presented in table 4C. The pattern is similar to table $4 \mathrm{~A}$ and $\mathrm{B}$, even though the coefficients are very small and rarely attain statistical significance. Exposure to fatal extreme events seems to have significantly more important consequences for LBW than for gestation. One possible reasons is that physical destruction could affect the infrastructure, resulting in worse food supply and lower hygene. Both of these factors could contribute to LBW independently of the effect on gestational age. Again, the effect appears to turn from negative to positive if the disaster struck more than 4 months before delivery. 
Table 4C: LBW by month of exposure; to avoid a large number of statistically insignificant zero coefficients, I report only variables with statistically significant coefficients

\begin{tabular}{|c|c|c|c|c|c|c|c|c|c|}
\hline \multicolumn{10}{|c|}{ Low birth weight } \\
\hline \multicolumn{2}{|l|}{$\begin{array}{l}\text { Exposure } \\
\text { time }\end{array}$} & \multicolumn{2}{|c|}{$\mathrm{N}$ disasters } & \multicolumn{3}{|c|}{ Binary Disaster } & \multicolumn{3}{|c|}{ With fatalities } \\
\hline \multirow{2}{*}{$\begin{array}{l}\text { Month } \\
\text { birth }\end{array}$} & 0.000 & 0.000 & 0.000 & 0.000 & 0.000 & 0.000 & 0.001 & 0.001 & 0.001 \\
\hline & $(0.000)$ & $(0.000)$ & $(0.000)$ & $(0.000)$ & $(0.000)$ & $(0.000)$ & (0.001) & (0.001) & (0.001) \\
\hline \multirow{2}{*}{$\begin{array}{l}\text { Month } \\
\text { before } \\
\text { birth }\end{array}$} & -0.000 & -0.000 & 0.000 & -0.000 & 0.000 & 0.000 & 0.001 & 0.001 & 0.001 \\
\hline & $(0.000)$ & $(0.000)$ & $(0.000)$ & $(0.000)$ & $(0.000)$ & $(0.000)$ & $(0.001)$ & $(0.001)$ & $(0.001)$ \\
\hline \multirow{2}{*}{$\begin{array}{l}2 \mathrm{~m} \\
\text { birth }\end{array}$} & 0.000 & 0.000 & 0.000 & 0.000 & 0.000 & $0.001 *$ & 0.001 & 0.001 & 0.001 \\
\hline & $(0.000)$ & $(0.000)$ & (0.000) & $(0.000)$ & $(0.000)$ & $(0.000)$ & (0.001) & (0.001) & (0.001) \\
\hline \multirow{2}{*}{$\begin{array}{l}3 \mathrm{~m} \\
\text { birth }\end{array}$} & 0.000 & -0.000 & 0.000 & 0.000 & 0.000 & 0.000 & $0.001^{*}$ & $0.001 *$ & $0.001 *$ \\
\hline & $(0.000)$ & $(0.000)$ & $(0.000)$ & $(0.000)$ & $(0.000)$ & $(0.000)$ & $(0.001)$ & $(0.001)$ & $(0.001)$ \\
\hline \multirow{2}{*}{$\begin{array}{l}4 \quad \mathrm{~m} \\
\text { birth }\end{array}$} & 0.000 & 0.000 & 0.000 & 0.000 & 0.000 & 0.000 & $-0.001^{*}$ & $-0.001 *$ & -0.001 \\
\hline & $(0.000)$ & $(0.000)$ & $(0.000)$ & $(0.000)$ & $(0.000)$ & $(0.000)$ & $(0.001)$ & $(0.001)$ & $(0.001)$ \\
\hline \multirow{2}{*}{$\begin{array}{l}5 \mathrm{~m} \\
\text { birth }\end{array}$} & -0.000 & -0.000 & -0.000 & $-0.000 *$ & $-0.000 *$ & -0.000 & $-0.001 *$ & $-0.001 *$ & -0.001 \\
\hline & $(0.000)$ & $(0.000)$ & $(0.000)$ & $(0.000)$ & $(0.000)$ & $(0.000)$ & $(0.001)$ & $(0.001)$ & (0.001) \\
\hline \multirow{2}{*}{$\begin{array}{l}6 \mathrm{~m} \\
\text { birth }\end{array}$} & -0.000 & -0.000 & 0.000 & -0.000 & -0.000 & 0.000 & -0.001 & -0.001 & -0.001 \\
\hline & $(0.000)$ & $(0.000)$ & (0.000) & $(0.000)$ & $(0.000)$ & $(0.000)$ & (0.001) & (0.001) & (0.001) \\
\hline \multirow{2}{*}{$\begin{array}{l}\text { Year FE } \\
\text { Month of } \\
\text { delivery } \\
\text { FE }\end{array}$} & YES & NO & NO & Yes & NO & NO & Yes & No & NO \\
\hline & Yes & NO & NO & Yes & NO & NO & Yes & NO & NO \\
\hline County FE & Yes & Yes & NO & Yes & Yes & NO & Yes & Yes & NO \\
\hline $\begin{array}{l}\text { Month- } \\
\text { year FE }\end{array}$ & NO & YES & NO & NO & YES & NO & NO & YES & NO \\
\hline $\begin{array}{l}\text { County- } \\
\text { year FE }\end{array}$ & NO & NO & YES & NO & NO & YES & NO & NO & YES \\
\hline \multirow[t]{2}{*}{ Constant } & $\begin{array}{l}0.072 * * \\
*\end{array}$ & $\begin{array}{l}0.071 * * \\
*\end{array}$ & $\begin{array}{l}0.065 * * \\
*\end{array}$ & $\begin{array}{l}0.072 * * \\
*\end{array}$ & $\begin{array}{l}0.071 * * \\
*\end{array}$ & $\begin{array}{l}0.065 * * \\
*\end{array}$ & $\begin{array}{l}0.072 * * \\
*\end{array}$ & $\begin{array}{l}0.071 * * \\
*\end{array}$ & $\begin{array}{l}0.065 * * \\
*\end{array}$ \\
\hline & $(0.001)$ & $(0.002)$ & $(0.000)$ & $(0.001)$ & $(0.002)$ & $(0.000)$ & $(0.001)$ & $(0.002)$ & $(0.000)$ \\
\hline $\begin{array}{l}\text { Observatio } \\
\text { ns }\end{array}$ & 695019 & 695019 & 695019 & 695019 & 695019 & 695019 & 695019 & 695019 & 695019 \\
\hline R-squared & 0.045 & 0.045 & 0.135 & 0.045 & 0.045 & 0.135 & 0.045 & 0.045 & 0.135 \\
\hline \multicolumn{10}{|c|}{ Robust standard errors in parentheses } \\
\hline * significant & at $10 \%$; * & ignifican & at $5 \%$; * & irnifi & at $1 \%$ & & & & \\
\hline
\end{tabular}

\subsection{Effects by gestational age, duration and severity}


Table 5 reports the estimations from a series of regressions of prematurity, gestational age, and LBW on the average duration of disasters in months 0 till -9 to delivery. Most of the action is the LBW outcome, which points to physical deprivation as an important contributor to LBW. An additional day of exposure in the $3^{\text {rd }}$ month before delivery increases the probability of an LBW birth by $2.18 \%$. An additional day in the $4^{\text {th }}$ month before delivery results in a $2.75 \%$ higher probability of LBW. The effects on prematurity and gestation are mixed and do not have enough statistical power to warrant strong conclusions.

Table 5: Differential effects by disaster duration; all coefficients multiplied by 100

\begin{tabular}{|c|c|c|c|}
\hline Mean duration of disasters & $(1)$ & $(2)$ & (3) \\
\hline Exposure period & Prematurity & Gestation & LBW \\
\hline Month of birth & $\begin{array}{l}-0.274 \\
(1.149)\end{array}$ & $\begin{array}{l}-9.044 \\
(12.921)\end{array}$ & $\begin{array}{l}1.213 \\
(0.999)\end{array}$ \\
\hline Month before birth & $\begin{array}{l}-0.352 \\
(1.143)\end{array}$ & $\begin{array}{l}-4.296 \\
(12.852)\end{array}$ & $\begin{array}{l}1.367 \\
(0.994)\end{array}$ \\
\hline 2 months to birth & $\begin{array}{l}0.117 \\
(1.147)\end{array}$ & $\begin{array}{l}-0.534 \\
(12.896)\end{array}$ & $\begin{array}{l}2.177 * * \\
(0.997)\end{array}$ \\
\hline 3 months to birth & $\begin{array}{l}-1.457 \\
(1.152)\end{array}$ & $\begin{array}{l}12.908 \\
(12.953)\end{array}$ & $\begin{array}{l}2.748 * * * \\
(1.001)\end{array}$ \\
\hline 4 months to birth & $\begin{array}{l}0.932 \\
(1.155)\end{array}$ & $\begin{array}{l}-13.706 \\
(12.997)\end{array}$ & $\begin{array}{l}0.859 \\
(1.004)\end{array}$ \\
\hline 5 months to birth & $\begin{array}{l}-1.196 \\
(1.161)\end{array}$ & $\begin{array}{l}7.706 \\
(13.074)\end{array}$ & $\begin{array}{l}1.311 \\
(1.009)\end{array}$ \\
\hline 6 months to birth & $\begin{array}{l}-1.040 \\
(1.249)\end{array}$ & $\begin{array}{l}-6.814 \\
(14.043)\end{array}$ & $\begin{array}{l}0.106 \\
(1.085)\end{array}$ \\
\hline 7 months to birth & $\begin{array}{l}-1.595 \\
(1.278)\end{array}$ & $\begin{array}{l}12.582 \\
(14.375)\end{array}$ & $\begin{array}{l}-0.559 \\
(1.111)\end{array}$ \\
\hline 8 months to birth & $\begin{array}{l}-0.262 \\
(1.274)\end{array}$ & $\begin{array}{l}-15.878 \\
(14.328)\end{array}$ & $\begin{array}{l}0.773 \\
(1.108)\end{array}$ \\
\hline 9 months to birth & $\begin{array}{l}0.081 \\
(1.247)\end{array}$ & $\begin{array}{l}-20.751 \\
(14.025)\end{array}$ & $\begin{array}{l}1.039 \\
(1.084)\end{array}$ \\
\hline Year-month FE & YES & YES & YES \\
\hline County-year FE & YES & YES & YES \\
\hline Constant & $\begin{array}{l}0.09 * * * \\
(0.000)\end{array}$ & $\begin{array}{l}39.540^{* * *} \\
(0.004)\end{array}$ & $\begin{array}{l}0.065^{* * *} \\
(0.000)\end{array}$ \\
\hline $\begin{array}{l}\text { Observations } \\
\text { R-squared }\end{array}$ & $\begin{array}{l}695019 \\
0.193\end{array}$ & $\begin{array}{l}695019 \\
0.190\end{array}$ & $\begin{array}{l}695019 \\
0.131\end{array}$ \\
\hline \multicolumn{4}{|c|}{ Standard errors in parentheses } \\
\hline
\end{tabular}


In table 6 I restrict the natural disasters to only those which caused more than 10 million in property damage. Since only the most destructive events are retained in the estimation, the control group consists of all mothers who experienced an event which resulted in less than 10 million in property damage or did not experience any extreme event. Indeed, the coefficients on exposure in different months are larger for the estimations in table 6. More physically damaging events are more harmful for pregnancy outcomes. Even if adverse weather and weather-related events do not increase in frequency, but increase in intensity, we can expect elevated rates of pre-term deliveries.

Table 6: The effects of extensive property damage; Binary exposure variable equal to 1 if the county-month cell experienced a disaster causing more than 10 million USD in property damage (2000 US dollars), 0 otherwise

\begin{tabular}{|c|c|c|c|}
\hline $\begin{array}{l}\text { Property damage over } 10 \\
\text { million }\end{array}$ & (1) & (2) & (3) \\
\hline Exposure period & Prematurity & Gestation & LBW \\
\hline \multirow[t]{2}{*}{ Month of birth } & 0.000 & -0.007 & $-0.003 *$ \\
\hline & $(0.002)$ & $(0.019)$ & $(0.001)$ \\
\hline \multirow[t]{2}{*}{ Month before birth } & $0.003 *$ & -0.021 & -0.001 \\
\hline & $(0.002)$ & $(0.019)$ & $(0.001)$ \\
\hline \multirow[t]{2}{*}{2 months to birth } & 0.001 & 0.005 & -0.000 \\
\hline & $(0.002)$ & (0.019) & $(0.001)$ \\
\hline \multirow[t]{2}{*}{3 months to birth } & $0.003 *$ & -0.010 & 0.001 \\
\hline & $(0.002)$ & $(0.020)$ & $(0.002)$ \\
\hline \multirow[t]{2}{*}{4 months to birth } & -0.001 & 0.009 & 0.001 \\
\hline & $(0.002)$ & $(0.020)$ & $(0.002)$ \\
\hline \multirow[t]{2}{*}{5 months to birth } & -0.002 & 0.013 & $-0.003 *$ \\
\hline & $(0.002)$ & $(0.020)$ & $(0.002)$ \\
\hline \multirow[t]{2}{*}{6 months to birth } & -0.001 & 0.016 & 0.000 \\
\hline & $(0.002)$ & $(0.019)$ & $(0.001)$ \\
\hline \multirow[t]{2}{*}{7 months to birth } & -0.002 & 0.012 & -0.001 \\
\hline & $(0.002)$ & $(0.019)$ & $(0.001)$ \\
\hline \multirow[t]{2}{*}{8 months to birth } & -0.001 & -0.026 & -0.001 \\
\hline & $(0.002)$ & $(0.020)$ & $(0.002)$ \\
\hline \multirow[t]{2}{*}{9 months to birth } & -0.001 & 0.003 & -0.001 \\
\hline & $(0.002)$ & $(0.019)$ & $(0.001)$ \\
\hline Year-month FE & YES & YES & YES \\
\hline County-year FE & YES & YES & YES \\
\hline \multirow[t]{2}{*}{ Constant } & $0.09 * * *$ & $39.538 * * *$ & $0.065 * * *$ \\
\hline & $(0.000)$ & $(0.005)$ & $(0.000)$ \\
\hline Observations & 695019 & 695019 & 695019 \\
\hline R-squared & 0.193 & 0.190 & 0.131 \\
\hline
\end{tabular}


Standard errors in parentheses

* significant at $10 \%$; ** significant at $5 \%$; *** significant at $1 \%$

\subsection{Effect on the number of births and alternative hypotheses}

A potential threat to the identification could come from differential reporting of residential location or differential change of residence between pre-term and full term births. For example, if mothers who were more likely to deliver prematurely are less likely to permanently relocate, then a significant effect of natural disasters on prematurity would be erroneously attributed to the effect of disasters. On the contrary, if pre-term birth mothers are more likely to relocate and report a different residence, then the regression coefficients on the effects of natural disasters will be attenuated towards 0 .

A few tests show that a spurious correlation between disasters and prematurity due to selective migration is unlikely. If some mothers change residence as a consequence of the extreme event, the number of births to mothers residing in the county should decrease. If there is selective dislocation on behalf of those less likely to have a premature delivery, then the number of premature births will increase relative to other months while the total number of births decreases. In sum, if the number of total births goes down, but the number of premature births goes up, there is reason to suspect differential re-location as an alternative explanation. 
Table 7 A: Number of births and the number of premature births by the count/indicator of extreme events

\begin{tabular}{llll}
\hline & $N$ births & $N$ premature & $N$ premature \\
\hline \multirow{3}{*}{ Month of delivery } & 0.140 & $0.025^{* * *}$ & \\
& $(0.097)$ & $(0.009)$ & 0.016 \\
Month before delivery & 0.044 & 0.008 & $(0.011)$ \\
& $(0.134)$ & $(0.011)$ & 0.005 \\
2 m to birth & $0.281^{* *}$ & 0.010 & $(0.014)$ \\
& $(0.121)$ & $(0.011)$ & -0.009 \\
3 m to birth & 0.071 & -0.015 & $(0.015)$ \\
& $(0.138)$ & $(0.013)$ & -0.019 \\
4 m to birth & 0.115 & -0.016 & $(0.016)$ \\
& $(0.076)$ & $(0.019)$ & -0.023 \\
5 m to birth & -0.195 & -0.024 & $(0.019)$ \\
& $(0.119)$ & $(0.019)$ & -0.011 \\
6 m to birth & -0.143 & -0.008 & $(0.014)$ \\
& $(0.105)$ & $(0.020)$ & 0.002 \\
7 m to birth & -0.143 & -0.020 & $(0.016)$ \\
& $(0.140)$ & $(0.021)$ & -0.011 \\
8 m to birth & -0.108 & $-0.045^{* *}$ & $(0.013)$ \\
& $(0.151)$ & $(0.018)$ & $-0.038^{* * *}$ \\
9 m to birth & -0.153 & -0.021 & $(0.011)$ \\
& $(0.148)$ & $(0.015)$ & -0.011 \\
N births & & & $(0.009)$ \\
& YES & YES & $0.065^{* * *}$ \\
Month of birth FE & YES & YES & $(0.006)$ \\
County*year FE & $73.179^{* * *}$ & $5.896^{* * *}$ & YES \\
Constant & $(0.441)$ & $(0.042)$ & YES \\
& 695019 & 695019 & $1.104^{* *}$ \\
Observations & 0.996 & 0.986 & $(0.465)$ \\
R-squared & & 695019 \\
Robust standard errors in parentheses & & 0.988 \\
\hline * significant at 10\%; $*$ significant at 5\%; *** significant at 1\% & \\
\hline
\end{tabular}

Table 7A reports on the number of total and preterm births by month of delivery and exposure in the nine months pre-delivery. If differential dislocation or reporting influences the results, the total number of births to mothers affected by a disaster in the month of delivery or the month before delivery should decrease, while the number of premature deliveries would increase. The pattern in columns 1 and 2 speaks of a different phenomenon. The total number of births to mothers residing in counties struck by a natural disaster in months 0 through -4 from delivery increases, while the number of births to mothers residing in counties struck by calamities in months -5 through -8 from 
delivery decreases. The number of premature births increases only if the disaster happened in the month of delivery, and in specification 3 which controls for the total number of births, there is no change in the count of preterm deliveries. There appears to be a mostly insignificant but negative effect on the number of premature deliveries for those affected in months 3 and more before delivery. These results suggest that there is little scope for selective migration affecting the proportion of premature births in a county. Yet the clear break in the pattern between 4 and 5 months before delivery suggests that those affected early enough in the gestation period behave differently than those affected later. Alternatively, there may be a natural tendency to report the new location as a county of residence of on has resided there for more than 4 months. It is still not clear whether disasters early on result in fewer deliveries because women permanently relocate or because they are not carried to term.

Another test can be done using neighboring counties which were differentially affected by extreme events. Studies of dislocated and evacuated persons show that the majority of those who do not stay in the county relocate to a neighboring area. Table 7B shows the results of regressions on two restricted samples: the county-month observations for counties which were not affected by any disaster in the 10 months before delivery, but a neighboring county was; and the sample of counties which were affected, but their neighboring counties were not. If a neighboring county was affected and full-term mothers from that neighboring county moved to the county that was not affected, then the number of premature births in that county will decrease relative to the total number of births. If the county itself was affected and the neighboring counties were not, then if full term mothers differentially migrated to neighboring counties, the total number of births would decrease and the number of premature births will increase. 
Table 7B: Effects on the total number of births and the number of premature births in neighboring counties

\begin{tabular}{|c|c|c|c|c|}
\hline Period of exposure & $N$ & $N$ premature & $N$ & $N$ premature \\
\hline & $\begin{array}{l}\text { None in } \\
\text { neighboring }\end{array}$ & $\begin{array}{l}\text { None in } \\
\text { neighboring }\end{array}$ & $\begin{array}{l}\text { None in home } \\
\text { county }\end{array}$ & $\begin{array}{l}\text { None in home } \\
\text { county }\end{array}$ \\
\hline Month of birth & $\begin{array}{l}-0.294 \\
(0.277)\end{array}$ & $\begin{array}{l}-0.018 \\
(0.051)\end{array}$ & $\begin{array}{l}0.286 \\
(0.175)\end{array}$ & $\begin{array}{l}0.027 \\
(0.037)\end{array}$ \\
\hline Month before birth & $\begin{array}{l}-0.465 \\
(0.284)\end{array}$ & $\begin{array}{l}-0.026 \\
(0.052)\end{array}$ & $\begin{array}{l}0.023 \\
(0.177)\end{array}$ & $\begin{array}{l}-0.033 \\
(0.037)\end{array}$ \\
\hline $2 \mathrm{~m}$ to birth & $\begin{array}{l}0.427 \\
(0.290)\end{array}$ & $\begin{array}{l}-0.019 \\
(0.053)\end{array}$ & $\begin{array}{l}-0.077 \\
(0.179)\end{array}$ & $\begin{array}{l}-0.009 \\
(0.037)\end{array}$ \\
\hline $3 \mathrm{~m}$ to birth & $\begin{array}{l}0.034 \\
(0.291)\end{array}$ & $\begin{array}{l}-0.098^{*} \\
(0.053)\end{array}$ & $\begin{array}{l}-0.155 \\
(0.179)\end{array}$ & $\begin{array}{l}0.051 \\
(0.037)\end{array}$ \\
\hline $4 \mathrm{~m}$ to birth & $\begin{array}{l}0.559 * \\
(0.291)\end{array}$ & $\begin{array}{l}0.035 \\
(0.053)\end{array}$ & $\begin{array}{l}-0.056 \\
(0.179)\end{array}$ & $\begin{array}{l}-0.007 \\
(0.037)\end{array}$ \\
\hline $5 \mathrm{~m}$ to birth & $\begin{array}{l}-0.649 * * \\
(0.291)\end{array}$ & $\begin{array}{l}-0.043 \\
(0.053)\end{array}$ & $\begin{array}{l}0.113 \\
(0.178)\end{array}$ & $\begin{array}{l}0.033 \\
(0.037)\end{array}$ \\
\hline $6 \mathrm{~m}$ to birth & $\begin{array}{l}-0.294 \\
(0.288)\end{array}$ & $\begin{array}{l}-0.083 \\
(0.053)\end{array}$ & $\begin{array}{l}0.166 \\
(0.179)\end{array}$ & $\begin{array}{l}0.002 \\
(0.037)\end{array}$ \\
\hline $7 \mathrm{~m}$ to birth & $\begin{array}{l}-0.547^{*} \\
(0.288)\end{array}$ & $\begin{array}{l}-0.031 \\
(0.053)\end{array}$ & $\begin{array}{l}0.309^{*} \\
(0.180)\end{array}$ & $\begin{array}{l}0.075^{* *} \\
(0.038)\end{array}$ \\
\hline $8 \mathrm{~m}$ to birth & $\begin{array}{l}-0.068 \\
(0.283)\end{array}$ & $\begin{array}{l}-0.104^{* *} \\
(0.052)\end{array}$ & $\begin{array}{l}0.378^{* *} \\
(0.178)\end{array}$ & $\begin{array}{l}-0.049 \\
(0.037)\end{array}$ \\
\hline $9 \mathrm{~m}$ to birth & $\begin{array}{l}-0.475^{*} \\
(0.280)\end{array}$ & $\begin{array}{l}-0.091 * \\
(0.051)\end{array}$ & $\begin{array}{l}0.092 \\
(0.178)\end{array}$ & $\begin{array}{l}-0.027 \\
(0.037)\end{array}$ \\
\hline Constant & $\begin{array}{l}76.547^{* * *} \\
(0.201)\end{array}$ & $\begin{array}{l}6.475^{* * *} \\
(0.037)\end{array}$ & $\begin{array}{l}58.888^{* * *} \\
(0.138)\end{array}$ & $\begin{array}{l}5.083^{* * *} \\
(0.029)\end{array}$ \\
\hline Observations & 177109 & 177109 & 178943 & 178943 \\
\hline R-squared & 0.997 & 0.989 & 0.997 & 0.986 \\
\hline
\end{tabular}

The regression results shown in table 7B generally support the hypothesis that some relocation takes place in neighboring counties in the wake of a natural calamity, but bear little evidence on differential dislocation of full-term mothers. The negative effect on the number of births in the affected county is stronger the longer time has elapsed between the event and the birth. Similarly, counties neighboring disaster affected areas experience the largest increase in the number of births to mothers affected 7 to 9 months before the delivery. These facts imply that relocation to neighboring areas is more likely if the disaster happened early in the gestation period. The number of premature births does not appear affected in any way consistent with differential relocation. 
While mothers appear to be relocating if affected before conception or in the early gestational period, there is little evidence that future premature births tend to relocate less than anyone else.

\section{Conclusions}

Predicting and estimating the effects of global climate change on health is an important area of research for social scientists. This paper offers the first evidence on the link between exposure to extreme weather events and pregnancy outcomes in the US for the period 1968-1988. Experiencing an extreme weather event during pregnancy increases the chances of premature delivery and decreases the average gestational age of infants. Considering the rising costs of immediate and longterm care for premature and low birth weight infants, this suggests that significant additional and indirect societal costs can be expected from increases in the frequency and severity of extreme weather events. If climate change does result in more frequent and severe weather-related disasters, those in utero may be among the first victims of human negligence.

\section{References:}

Bouma, ML et al “Global Assessment of El Nino’s Disaster Burden” Lancet 1997; 350: 1435-38

Deschenes, Olivier and Enrico Moretti (2007) “Extreme Weather Events, Mortality and Migration” NBER Working Paper 13227

Deschenes, Olivier and Michael Greenstone (2007) "Climate Change, Mortality, and Adaptation: Evidence from Annual Fluctuations in Weather in the US”NBER Working Paper 13178

Freedy, John et al (1994) "Understanding Acute Psychological Distress Following Natural Disaster”, Journal of Traumatic Stress, 7 (2)

Glynn, Laura M et al. (2001) "When Stress Happens Matters: Effects of Earthquake timing on Stress Responsivity in Pregnancy” American Journal of Obstetrics and Gynecology, Vol. 184(4) March 2001

Krug, Etienne et al (1999) “Suicide after Natural Disasters” NEJM 340(2):148

Maida, CA et al (1989) "Psychological Impact of disasters: victims of the Baldwin Hills Fire" Journal of Traumatic Stress 1989: 10

March of Dimes Foundation (2008) "The Cost of Prematurity to US Employers" http://marchofdimes.com/peristats/pdfdocs/cts/ThomsonAnalysis2008_SummaryDocument_final12 1208.pdf accessed on March 25th, 2009 
Meehl, GA and Tebaldi, C. "More Intense, More Frequent, and Longer Lasting Heat Waves in the $21^{\text {st }}$ Century: Science 2004; 305: 994-97

Ollendick, DG and Hoffmann M “Assessment of Psychological reactions in Disaster Victims” Journal of Community Psychology 1982; 10

Shore JH, Tatum EL, Vollmer WM Evaluation of Mental Effects of disaster, Mount St. Helens Eruption” American Journal of Public Health, 186; 15 (13) 


\section{CESifo Working Paper Series}

for full list see www.cesifo-group.org/wp

(address: Poschingerstr. 5, 81679 Munich, Germany, office@cesifo.de)

2753 Daniel G. Arce, Dan Kovenock and Brian Roberson, Suicide Terrorism and the Weakest Link, August 2009

2754 Mario Larch and Wolfgang Lechthaler, Comparative Advantage and Skill-Specific Unemployment, August 2009

2755 Horst Raff and Nicolas Schmitt, Buyer Power in International Markets, August 2009

2756 Seppo Kari, Hanna Karikallio and Jukka Pirttilä, The Impact of Dividend Taxation on Dividends and Investment: New Evidence Based on a Natural Experiment, August 2009

2757 Mirco Tonin and Michael Vlassopoulos, Disentangling the Sources of Pro-social Behavior in the Workplace: A Field Experiment, August 2009

2758 Nicole Grunewald and Inmaculada Martínez-Zarzoso, Driving Factors of Carbon Dioxide Emissions and the Impact from Kyoto Protocol, August 2009

2759 Yu-Fu Chen and Michael Funke, Booms, Recessions and Financial Turmoil: A Fresh Look at Investment Decisions under Cyclical Uncertainty, August 2009

2760 Jan-Egbert Sturm and Jakob de Haan, Does Central Bank Communication really Lead to better Forecasts of Policy Decisions? New Evidence Based on a Taylor Rule Model for the ECB, August 2009

2761 Larry Karp, Sacrifice, Discounting and Climate Policy: Five Questions, August 2009

2762 Marianna Belloc and Samuel Bowles, International Trade, Factor Mobility and the Persistence of Cultural-Institutional Diversity, August 2009

2763 Charles Noussair and Fangfang Tan, Voting on Punishment Systems within a Heterogeneous Group, August 2009

2764 Birgit Bednar-Friedl and Karl Farmer, Internationally Coordinated Emission Permit Policies: An Option for Withdrawers from the Kyoto Protocol?, August 2009

2765 Pierre M. Picard and David E. Wildasin, Labor Market Pooling, Outsourcing and Labor Contracts, August 2009

2766 Stefan Voigt and Lorenz Blume, The Economic Effects of Federalism and Decentralization - A Cross-Country Assessment, August 2009

2767 David S. Jacks, Christopher M. Meissner and Dennis Novy, Trade Booms, Trade Busts, and Trade Costs, August 2009 
2768 Mario Jametti and Thomas von Ungern-Sternberg, Hurricane Insurance in Florida, August 2009

2769 Alessandro Balestrino, Kind of Black: The Musicians' Labour Market in Italy, August 2009

2770 Yosr Abid Fourati and Cathal O’Donoghue, Eliciting Individual Preferences for Pension Reform, August 2009

2771 Christian Breuer and Chang Woon Nam, VAT on Intra-Community Trade and Bilateral Micro Revenue Clearing in the EU, August 2009

2772 Choudhry Tanveer Shehzad, Jakob De Haan and Bert Scholtens, Growth and Earnings Persistence in Banking Firms: A Dynamic Panel Investigation, August 2009

2773 Erdal Yalcin, Uncertain Productivity Growth and the Choice between FDI and Export, August 2009

2774 Klaus Abberger, Wolfgang Nierhaus and Shynar Shaikh, Findings of the Signal Approach for Financial Monitoring in Kazakhstan, September 2009

2775 Sascha O. Becker, Francesco Cinnirella and Ludger Woessmann, The Trade-off between Fertility and Education: Evidence from before the Demographic Transition, September 2009

2776 Thomas Aronsson and Erkki Koskela, Optimal Income Taxation, Outsourcing and Policy Cooperation in a Dynamic Economy, September 2009

2777 Joel Slemrod, Old George Orwell Got it Backward: Some Thoughts on Behavioral Tax Economics, September 2009

2778 Cagri Seda Kumru and Athanasios C. Thanopoulos, Social Security Reform and Temptation, September 2009

2779 Alessandro Bucciol and Roel M. W. J. Beetsma, Inter- and Intra-generational Consequences of Pension Buffer Policy under Demographic, Financial and Economic Shocks, September 2009

2780 Eduardo Strube and Marcelo Resende, Complementarity of Innovation Policies in the Brazilian Industry: An Econometric Study, September 2009

2781 Henry Tulkens and Vincent van Steenberghe, "Mitigation, Adaptation, Suffering": In Search of the Right Mix in the Face of Climate Change, September 2009

2782 Maria L. Loureiro, Anna Sanz-de-Galdeano and Daniela Vuri, Smoking Habits: Like Father, Like Son, Like Mother, Like Daughter, September 2009

2783 Momi Dahan, Tehila Kogut and Moshe Shalem, Do Economic Policymakers Practice what they Preach? The Case of Pension Decisions, September 2009 
2784 Eytan Sheshinski, Uncertain Longevity and Investment in Education, September 2009

2785 Nannette Lindenberg and Frank Westermann, How Strong is the Case for Dollarization in Costa Rica? A Note on the Business Cycle Comovements with the United States, September 2009

2786 Leif Danziger, Noncompliance and the Effects of the Minimum Wage on Hours and Welfare in Competitive Labor Markets, September 2009

2787 Gerlinde Fellner, Rupert Sausgruber and Christian Traxler, Testing Enforcement Strategies in the Field: Legal Threat, Moral Appeal and Social Information, September 2009

2788 Gabriel J. Felbermayr, Mario Larch and Wolfgang Lechthaler, Unemployment in an Interdependent World, September 2009

2789 Sebastian G. Kessing, Federalism and Accountability with Distorted Election Choices, September 2009

2790 Daniel Gros, Global Welfare Implications of Carbon Border Taxes, September 2009

2791 Louis N. Christofides, Michael Hoy and Ling Yang, The Gender Imbalance in Participation in Canadian Universities (1977-2005), September 2009

2792 Jan K. Brueckner and Robert W. Helsley, Sprawl and Blight, September 2009

2793 Vidar Christiansen and Stephen Smith, Externality-correcting Taxes and Regulation, September 2009

2794 John Beirne, Guglielmo Maria Caporale, Marianne Schulze-Ghattas and Nicola Spagnolo, Global and Regional Spillovers in Emerging Stock Markets: A Multivariate GARCH-in-mean Analysis, September 2009

2795 Rüdiger Pethig and Frieder Kolleß, Asymmetric Capital-Tax Competition, Unemployment and Losses from Capital Market Integration, September 2009

2796 Ngo Van Long, Horst Raff and Frank Stähler, Innovation and Trade with Heterogeneous Firms, September 2009

2797 Margit Osterloh and Bruno S. Frey, Research Governance in Academia: Are there Alternatives to Academic Rankings?, September 2009

2798 Thiess Buettner and Clemens Fuest, The Role of the Corporate Income Tax as an Automatic Stabilizer, September 2009

2799 Annette Alstadsæter, Measuring the Consumption Value of Higher Education, September 2009

2800 Peter Friedrich, Chang Woon Nam and Janno Reiljan, Local Fiscal Equalization in Estonia: Is a Reform Necessary?, September 2009 
2801 Evžen Kočenda and Jan Hanousek, State Ownership and Control in the Czech Republic, September 2009

2802 Michael Stimmelmayr, Wage Inequality in Germany: Disentangling Demand and Supply Effects, September 2009

2803 Biswa N. Bhattacharyay, Towards a Macroprudential Surveillance and Remedial Policy Formulation System for Monitoring Financial Crisis, September 2009

2804 Margarita Katsimi, Sarantis Kalyvitis and Thomas Moutos, "Unwarranted" Wage Changes and the Return on Capital, September 2009

2805 Christian Lessmann and Gunther Markwardt, Aid, Growth and Devolution, September 2009

2806 Bas Jacobs and Dirk Schindler, On the Desirability of Taxing Capital Income to Reduce Moral Hazard in Social Insurance, September 2009

2807 Hans Gersbach and Noemi Hummel, Climate Policy and Development, September 2009

2808 David E. Wildasin, Fiscal Competition for Imperfectly-Mobile Labor and Capital: A Comparative Dynamic Analysis, September 2009

2809 Johan Eyckmans and Cathrine Hagem, The European Union's Potential for Strategic Emissions Trading through Minimal Permit Sale Contracts, September 2009

2810 Ruediger Bachmann and Christian Bayer, The Cross-section of Firms over the Business Cycle: New Facts and a DSGE Exploration, October 2009

2811 Slobodan Djajić and Michael S. Michael, Temporary Migration Policies and Welfare of the Host and Source Countries: A Game-Theoretic Approach, October 2009

2812 Devis Geron, Social Security Incidence under Uncertainty Assessing Italian Reforms, October 2009

2813 Max-Stephan Schulze and Nikolaus Wolf, Economic Nationalism and Economic Integration: The Austro-Hungarian Empire in the Late Nineteenth Century, October 2009

2814 Emilia Simeonova, Out of Sight, Out of Mind? The Impact of Natural Disasters on Pregnancy Outcomes, October 2009 